\title{
Pertanggungjawaban Pidana Terhadap Pelaku Tindak Pidana Laka Lantas Di Bawah Umur (Satlantas Polres Langkat)
}

\section{Criminal Liability For Underage Traffic Accident Perpetrators (Langkat Traffic Police Unit)}

\author{
Simon Elika Simatupan*, Alpi Sahari \& Surya Perdana \\ Program Studi Magister Ilmu Hukum, Universitas Muhammadiyah Sumatera Utara, \\ Indonesia
}

Diterima: 21 Juli 2020; Direview: 02 Agustus 2020; Disetujui: 28 Agustus 2020

\section{*Email: Simonelikasimatupang@gmail.com}

\begin{abstract}
Abstrak
Pelanggaran laka lantas yang dilakukan oleh anak dibawah umur layak mendapatkan perhatian khusus dan serius dari pemerintah. Dalam kasus ini perlu adanya proses penyidikan khusus terhadap pelaku anak dibawah umur dan pertanggungjawaban anak tersebut terhadap tindak pidana yang telah dilakukan. Penelitian ini bertujuan untuk menganalisis proses penyidikan kepolisian terhadap pelaku laka lantas dibawah umur dan mengenai pertanggungjawaban pelaku menyesuaikan dengan UU No.23 Tahun 2002 tentang Pelindungan Anak Jo UU No.35 Tahun 2014 dalam wilayah hukum Satlantas Polres Langkat. Metode penelitan pada tulisan ini menggunakan metode penelitian normatif yang bersifat deskriptif analisis dengan pendekatan undang-undang, konseptual dan kasus serta sumber data skunder. Hasil penulisan ini menunjukkan bahwa dalam proses penyidikan terhadap anak berupa penangkapan, penahanan dan pidana penjara dapat dilakukan sebagai upaya terakhir karena terdapat perbedaan dalam proses pertanggaungjawaban pidana dengan pelaku orang dewasa. Upaya yang dilakukan oleh pihak kepolisian adalah dengan menerima laporan dari korban dan menerapkan restorative justice dengan mengupayakan sistem disversi.
\end{abstract}

Kata Kunci: Pertanggungjawaban, Laka Lantas, Anak

\begin{abstract}
The mere violations committed by minors deserve special and serious attention from the government. In this case, it is necessary to have a process of special investigation of the perpetrators of minors and the responsibility of the perpetrators to adjust to Law No.23 of 2002 concerning Child Protection Jo Law No. 35 of 2014 in the jurisdiction of the Traffic Police Traffic Unit of Langkat. The research method in this paper used a normative research method which is descriptive in nature withe a legal, conceptual and case approach and secendary data sources. The result of this writing show that in the process of investigating children in the form of arrest, detention and impriosonment can be done as a last resort because there are differences in the criminal accountability process with adult offenders. The effort made by the police is to receive reports from victims and implement restorative justice by pursuing a system of disruption.
\end{abstract}

Keywords: Criminal lialibility, Traffic Accident, Children

How to Cite: Simatupan, S.E. Sahari, A. \& Perdana, S. (2020). Pertanggungjawaban Pidana Terhadap Pelaku Tindak Pidana Laka Lantas Di Bawah Umur (Satlantas Polres Langkat). Journal of Education, Humaniora and Social Sciences (JEHSS). 3 (2): 310-316. 
Masalah lalu lintas merupakan salah satu masalah yang berskala nasional yang berkembang seirama dengan perkembangan masyarakat. Lalu lintas kendaraan yang beraneka ragam dan pertambahan jumlah kendaraan yang lebih cepat dibandingkan dengan pertambahan prasarana jalan yang mengakibatkan berbagai masalah lalu lintas seperti kemacetan dan kecelakaan lalu lintas. Kecelakaan lalu lintas (laka lantas) masih menjadi masalah serius di Indonesia. Pengaturan hukum di Indonesia mengenai lalulintas diatur oleh Undang-Undang Nomor 14 Tahun 1992 tentang Lalulintas dan Angkutan Jalan, yang kemudian sekarang dirubah menjadi Undang-Undang Nomor 22 Tahun 2009 tentang Lalulintas dan Angkutan Jalan.

Di Indonesia, kecelakaan lalu lintas (laka lantas) yang melibatkan anak dibawah umur menjadi perhatian khusus dan serius pemerintah Indonesia. Longgarnya kedisiplinan berkendara dan kontrol dari orangtua si anak, membuat banyak anak di bawah umur bebas berkeliaran mengendarai kendaraan bermotor, sehingga mereka rentan menjadi pelaku dan korban kecelakaan lalu lintas. Anak sebagai pelaku tindak pidana disebut juvenile delinquency adalah setiap perbuatan atau tingkah laku seorang anak dibawah umur 18 (delapan belas) tahun dan belum kawin yang merupakan pelanggaran terhadap norma-norma hukum yang berlaku serta dapat membahayakan perkembangan pribadi anak (Atmasasmita, 1983).

Kenakalan anak (khususnya yang berupa tindak pidana) setiap tahun selalu meningkat. Salah satu upaya cara pencegahan dan penanggulangan kenakalan anak (politik kriminal anak) saat ini melalui penyelanggaraan system peradilan pidana. Tujuan penyelenggaraan system peradilan anak (juvenile justice) tidak semata-mata bertujuan untuk menjatuhkan sanksi pidana anak pelaku pidana tetapi lebih fokus pada dasar pemikiran bahwa penjatuhan sanksi tersebut sebagai sarana mendukung mewujudkan kesejahteraan anak pelaku tindak pidana. Anak yang melakukan suatu tindak pidana bukanlah tidak dapat dihukum, namun sebisa mungkin hukuman yang diberikan tidaklah berat.Keberadaan Undang-Undang Nomor 11 Tahun 2012 tentang Sistem Peradilan Pidana Anak, maka memberikan landasan hukum yang kuat untuk membedakan perlakuan terhadap anak yang berhadapan dengan hukum. Perlakuan hukum pada anak dibawah umur pada perkara penyalahgunaan narkoba sudah selayaknya mendapatkan perhatian khusus dari aparat penegak hukum dalam memproses dan memberikan sanksi pidana (Wahyuni et al., 2020; Ikhwan et al., 2020; Dermawan, 2020; Siregar etal., 2019).

Dalam menangani perkara anak di kepolisian Polres Langkat dalam hal ini penyidik harus memperhatikan prinsip kepentingan terbaik bagi Anak dan mengusahakan agar suasana kekeluargaan tetap terpelihara. Pada tingkat penyidikan, pemeriksaan perkara anak wajib diupayakan Diversi, dengan syarat tindak pidana yang dilakukan; diancam dengan pidana penjara paling lama 7 (tujuh) tahun dan bukan merupakan pengulangan tindak pidana. Keputusan diversi harus mendapatkan persetujuan korban dan keluarganya serta kesediaan anak dan keluarganya, kecuali tindak pidana berupa pelanggaran, tindak pidana ringan, tindak pidana tanpa korban, atau nilai kerugian korban tidak lebih dari nilai upah minimum provinsi setempat.

Berdasarkan pada kasus penelitian ini maka pihak yang menyebabkan kecelakaan lalulintas (lakalantas) yang mengakibatkan korban mengalami luka berat akan diproses dengan tindak pidananya (wawancara Bapak AKP. Arnold Hasibuan, 2019).

Pada awalnya pelaku yang masih berusia dibawah umur mengendarai sepeda motor berboncengan dengan kecepatan tinggi. Kemudian sepeda motor yang dikendarai tersebut tidak dapat dikuasai oleh pelaku dan menabrak korban yang sedang menyeberangi jalan dan menabrak korban. Korban langsung mengalami luka berat. Langkah upaya yang dilakukan Satlantas Polres Langkat dalam penanganan tindak pidana laka lantas terhadap pelaku anak dibawah umur, penyidik wajib untuk memediasi kedua belah pihak yang terlibat adalah telah menerima laporan dari korban, lalu terbit Laporan Polisi (LP) kemudian dibuatkan Surat Perintah Penyidikan dan penyidik dengan menerapkan restorative justice dengan mengupayakan sistem diversi, penyidik mengirim surat Ke Balai Pemasyarakatan (Bapas) dengan tujuan untuk pendampingan terhadap pelaku anak dibawah umur tindak pidana laka lantas dan melakukan 
penelitian masyarakat dan mendampingi selama penyidikan (wawancara Bapak AKP. Arnold Hasibuan;2019).

\section{METODE PENELITIAN}

Dalam penelitian ini, penulis menggunakan jenis penelitian hukum normatif dan penelitian empiris. Penelitian hukum normatif, yang juga disebut sebagai penelitian perpustakaan atau studi dokumen, karena lebih banyak dilakukan terhadap data yang bersifat sekunder yang ada diperpustakaan (Ediwarman, 2014). Penelitian hukum normatif juga mengacu kepada aturanaturan hukum, norma-norma hukum yang terdapat baik didalam ketentuan peraturan perundang-undangan maupun didalam putusan pengadilan. Penelitian hukum empiris merupakan penelitian hukum yang memakai sumber data primer, yang mana data yang diperoleh berasal dari data yang berkaitan dengan kasus kecelakaan lalu lintas dengan pelaku anak dibawah umur (Ediwarman, 2014). Metode pendekatan yang dilakukan dalam penelitian ini menggunakan 3 pendekatan, yaitu: pendekatan perundang-undangan (statute approach), pendekatan konseptul (conceptual approach), dan pendekatan kasus (case approach).

Prosedur pengambilan dan pengumpulan data dilakukan dengan cara studi kepustakaan (library research). Studi kepustakaan (library research) adalah serangkaian usaha untuk memperoleh data dengan jalan membaca, menelaah, mengklarifikasi, mengidentifikasi, dan dilakukan pemahaman terhadap bahan-bahan hukum yang berupa peraturan perundangundangan serta buku-buku literatur yang ada relevansinya dengan permasalahan penelitian, dan selain mengumpulkan data dengan cara studi kepustakaan, studi dokumen, penelitian ini juga didukung dengan teknik studi lapangan field research (Soekanto, 2004).

Untuk memperoleh data, seorang peneliti biasanya menggunakan instrument mengumpulkan data, dan alat pengumpulan data yang digunakan dalam penelitian ini adalah dengan menggunakan studi dokumen dan membuat pedoman wawancara serta melakukan wawancara mendalam (depth interview) kepada informan yaitu Pejabat Kepolisian Satlantas Polres Langkat.

\section{HASIL DAN PEMBAHASAN}

\section{Proses Penyikan Kepolisian Dalam Tindak Pidana Laka Lantas Terhadap Anak Dibawah Umur Wilayah Hukum Satlantas Polres Langkat}

Dewasa ini, perkembangan kasus kecelakaan lalu lintas di Indonesia semakin meningkat. Padatnya kendaraan dan semakin sempitnya ruas jalan untuk kendaraan bermotor menambah panjang daftar laka lantas di Indonesia. Hal ini semakin diperburuk dengan fakta bahwa banyak anak dibawah umur mengantongi ijin untuk mengendarai kendaraan bermotor dari orang tua mereka. Sebagian alasan memperbolehkan anak-anak tersebut untuk mengendarainya adalah untuk mempermudah akses dan meminimalisir anggaran pengeluaran transportasi mereka. Akibatnya, banyaknya kecelakaan lalu lintas yang terjadi di dominasi dengan korban anak dan pelaku anak dibawah umur.

Di Indonesia memiliki berbagai ketentuan peraturan perundangundangan mengenai tindak pidana yang dilakukan oleh anak dibawah umur. Pengertian anak menurut ketentuan UndangUndang Nomor 3 Tahun 1997 tentang Pengadilan Anak pasal 1 angka 1 dan angka 2 perihal ketentuanumum adalah sebagi berikut :Pasal 1 angka 1, anak adalah orang yang dalam perkara anak nakal telah mencapai umur 8(delapan) tahun tetapi belum mancapai umur 18 (delapan belas) tahun dan belum pernah kawin.

Dalam menangani perkara anak dikepolisian Polres Langkat dalam hal ini penyidik harus memperhatikan prinsip kepentingan terbaik bagi Anak dan mengusahakan agar suasana kekeluargaan tetap terpelihara. Pada tingkat penyidikan, pemeriksaan perkara anak wajib diupayakan Diversi, dengan syarat tindak pidana yang dilakukan; diancam dengan pidana penjara paling lama 7 (tujuh) tahun dan bukan merupakan pengulangan tindak pidana.

Keputusan diversi harus mendapatkan persetujuan korban dan keluarganya serta kesediaan anak dan keluarganya, kecuali tindak pidana berupa pelanggaran, tindak pidana ringan, tindak pidana tanpa korban, atau nilai kerugian korban tidak lebih dari nilai upah

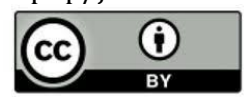


minimum provinsi setempat. Kesepakatan diversi untuk tindak pidana berupa pelanggaran, tindak pidana ringan, tindak pidana tanpa korban, atau nilai kerugian korban tidak lebih dari nilai upah minimum provinsi setempat, dapat dilakukan oleh penyidik, bersama pelaku dan/atau keluarganya, pembimbing kemasyarakatan, serta dapat melibatkan tokoh masyarakat.

Dalam hal proses diversi tidak menghasilkan kesepakatan atau kesepakatan diversi tidak dilaksanakan, maka proses peradilan pidana anak dilanjutkan, danregister perkara anak pada kepolisian dibuat secara khusus.

Terkait dengan penelitian ini, bahwa pengaturan hukum tindak pidana lakalantas yang dilakukan oleh anak dibawah umur di wilayah hukum Satlantas Polres Langkat. Berdasarkan pada kasus penelitian ini maka pihak yang menyebabkan kecelakaan lalulintas (lakalantas) yang mengakibatkan korban mengalami luka berat akan diproses dengan tindak pidananya (wawancara Bapak AKP. Arnold Hasibuan;2019).

Langkah upaya yang dilakukan Satlantas Polres Langkat dalam penanganan tindak pidana laka lantas terhadap pelaku anak dibawah umur, penyidik wajib untuk memediasi kedua belah pihak yang terlibat adalah telah menerima laporan dari korban, lalu terbit Laporan Polisi (LP) kemudian dibuatkan Surat Perintah Penyidikan dan penyidik dengan menerapkan restorative justice dengan mengupayakan sistem diversi, penyidik mengirim surat Ke Balai Pemasyarakatan (Bapas) dengan tujuan untuk pendampingan terhadap pelaku anak dibawah umur tindak pidana laka lantas dan melakukan penelitian masyarakat dan mendampingi selama penyidikan (wawancara Bapak AKP. Arnold Hasibuan, 2019).

Pelaku tindak pidana lakalantas adalah seorang anak yang masih berusia dibawah umur pada suatu tempat yang masih termasuk dalam wilayah hukum Satlantas POLRES Langkat, melakukan kelalaian lalu lintas yang menyebabkan korban mengalami luka berat. Pelaku (berusia dibawah umur) mengendarai sepeda motor tersebut tiba-tiba tidak bisa menguasai motornya yang melaju dengan kecepatan tinggi dan menabrak korban langsung.

Berdasarkan fakta-fakta yang terungkap baik yang terurai dari keterangan saksi-saksi maupun bukti surat hasil visum dan keterangan pelaku (berusia dibawah umur),bahwa perbuatan pelaku (masih berusia umur) telah dapat dibuktikan secara sah dan meyakinkan memenuhi rumusan tindak pidana yang dikenakan Pasal 310 ayat (3) UU RI No. 22 tahun 2009 tentang Lalulintas dan Angkutan Jalan (wawancara Bapak AKP. Arnold Hasibuan;2019).

Perbuatan pelaku (masih berusia umur) telah dapat dibuktikan secara sah dan meyakinkan memenuhi rumusan tindak pidana yang dikenakan Pasal 310 ayat (3) UU No. 22 tahun 2009 tentang Lalulintas dan Angkutan Jalan, yang unsur-unsurnya adalah sebagai berikut:

1. Setiap orang;

2. Yang mengemudikan kendaraan bermotor;

3. Karena kelalaiannya;

4. Mengakibatkan kecelakaan lalu lintas dengan korban luka berat.

Penyidikan oleh Kepolisian harus terlebih dahulu mengetahui adanya suatu tindak pidana yang terjadi. Sebagaimana diatur Pasal 106 Kitab Undang-Undang Hukum Acara Pidana (KUHAP) merumuskan bahwa: "Penyidik yang mengetahui, menerima laporan atau pengaduan tentang terjadinya suatu peristiwa pidana yang patut diduga merupakan tindak pidana wajib segera melakukan tindakan penyelidikan yang diperlukan"

Suatu penyidikan dimulai dengan konskuensi penggunaan upaya paksa, terlebih dahulu perlu ditentukan secara cermat berdasarkan data yang diperoleh dari hasil penyelidikan bahwa suatu peristiwaa atau tindak pidana yang semula diduga sebagai suatu tindak pidana adalah benar-benar merupakan tindak pidana (Husein, 1991).

Dengan demikian penyidikan merupakan suatu proses atau langkah awal yang merupakan suatu proses penyelesaian suatu tindak pidana yang perlu diselidik dan diusut secara tuntas didalam sistem peradilan pidana, dari pengertian tersebut, maka bagian-bagian dari hukum acara pidana yang menyangkut tentang penyidikan adalah sebagai berikut: ketentuan-ketentuan tentang alat-alat bukti, ketentuan tentang terjadinya delik, pemeriksaan ditempat kejadian, pemanggilan tersangka atau terdakwa, penahanan sementara, penggeledahan, pemeriksaan dan 
introgasi, berita acara, penyampingan perkara, pelimpahan perkara kepada Penuntut Umum dan pengembalian kepada penyidik untuk disempurnakan (Hamzah, 2002).

Penyidikan tindak pidana lakalantas, dilakukan oleh pejabat penyidik Kepolisian, selain itu pejabat pegawai negri sipil tertentu yang lingkup tugas dan tanggungjawabnya meliputi lalulintas, diberi wewenang khusus sebagai penyidik sebagaimana dimaksud dalam KUHAP yang juga diatur dalam UU No. 22 tahun 2009 tentang Lalulintas dan Angkutan Jalan.

Pelaku yang masih berusia dibawah umur mengendarai kenderaan speda motornya melacu dengan kecepatan tinggi sehingga tiba-tiba tidak dapat mengendalikan kenderaan sepeda motornya, kemudian menyebabkan menabrak korban yang sedang menyebrang jalan dan korban mengalami luka patah tulang dan luka dikepala korban (wawancara Bapak AKP. Arnold Hasibuan;2019).

Dilakukan pemeriksaan oleh penyidik bagian Satlantas di Polres Langkat, penyidik telah memanggil dan memeriksa beberapa orang saksi, alat bukti beserta untuk memperkuat hasil penyidikannya, atas keterangan saksi-saksi tersebut, pelaku (anak masih berusia dibawah umur) membenarkannnya perbuatannya, alat bukti yang diperoleh berupa; Visum Et Repertum dari UPTD Puskesmas Langkat tanggal 25 April 2018 terhadap korban.

Perbuatan pelaku (anak asih berusia dibawah umur) diduga telah melanggar tindak pidana lakalantas sebagaimana diatur Pasal 310 UU No. 22 Tahun 2009 tentang Lalulintas dan Angkutan Jalan, yakni: "bahwa "setiap orang yang mengemudikan Kendaraan Bermotor yang karena kelalaiannya mengakibatkan Kecelakaan Lalu Lintas dengan korban luka berat sebagaimana dimaksud dalam Pasal 229 ayat (4), dipidana dengan pidana penjara paling lama 5 (lima) tahun dan/atau denda paling banyak Rp10.000.000,00 (sepuluh juta rupiah).

Pasal 229 ayat (4) UU No. 22 Tahun 2009 tentang Lalulintas dan Angkutan Jalan menyatakan bahwa "kecelakaan Lalu Lintas berat sebagaimana dimaksud pada ayat (1) huruf c merupakan kecelakaan yang mengakibatkan korban meninggal dunia atau luka berat."

\section{Pertanggungjawaban Pidana Tindak Pidana Laka Lantas Terhadap Pelaku Dibawah Umur Di Wilayah Hukum Satlantas Polres Langkat}

Pertanggungjawaban adalah kewajiban terhadap segala sesuatunya, fungsi menerima pembebanan sebagai akibat dari sikap tindakan sendiri atau pihak lain (Poerwadarminta, 1985) Pertanggungjawaban pidana dalam istilah asing tersebut juga dengan teorekenbaardheid atau criminalresponsibility yang menjurus kepada pemidanaan petindak dengan maksud untuk menentukan apakah seseorang terdakwa atau tersangka dipertanggung jawabkan atas suatu tindakan pidana yang terjadi atau tidak.

Pertanggungjawaban pidana pada hakikatnya mengandung makna pencelaan pembuat (subjek hukum) atas tindak pidana yang telah dilakukannya, oleh karena itu, pertanggungjawaban pidana mengandung di dalamnya pencelaan objektif dan pencelaan subjektif. Artinya, secara objektif si pembuat telah melakukan tindak pidana (perbuatan terlarang/melawan hukum dan diancam pidana menurut hukum yang berlaku) dan secara subjektif si pembuat patut dipertanggungjawabkan atas tindak pidana yang dilakukannya itu sehingga ia patut di pidana (Bunga, 2012)

Kemampuan bertanggungjawab merupakan unsur kedua dari kesalahan yang harus terpenuhi untuk memastikan bahwa pelaku tindak pidana dapat mempertanggungjawabkan perbuatannya atau dapat dipidana. Kemampuan bertanggungjawab biasanya dikaitkan dengan keadaan jiwa pelaku tindak pidana, yaitu bahwa pelaku dalam keadaan sehat jiwanya atau tidak pada saat melakukan tindak pidana.

Kemampuan seseorang dapat mempertanggungjawabkan perbuatannya dapat dilihat dari kemampuan individu tersebut dalam membedakan perbuatan yang baik dan yang buruk (sesuai dengan hukum dan yang melawan hukum) dan memiliki kemampuan untuk menentukan kehendaknya menurut keinsyafan tentang baik dan buruknya suatu perbuatan. Selain itu berdasarkan undang-undang ada beberapa hal yang menyebabkan pelaku tindak pidana tidak mampu bertanggungjawab, misalnya masih dibawah umur, ingatannya terganggu oleh penyakit, daya paksa, pembebanan terpaksa yang melampaui batas. Apabila keadaan-keadaan tersebut

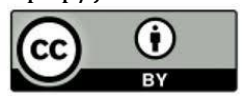


melekat pada pelaku tindak pidana, maka undang-undang memaafkan pelaku, sehingga terbebas atau lepas dari segala tuntutan hukum.

Berkaitan dengan persoalan pertanggung jawaban seorang anak yang masih dibawah umur anak dapat dimintai pertanggung jawaban, pertanggungjawaban pidana anak dibawah umur yang terdapat diluar KUHP, dalam pemberian hukuman sanksi pidana, tidak hanya dapat dilihat dalam ketentuan hukuman yang terdapat dalam KUHP sebagai hukum materil.

Adanya perbedaan dalam pemberian sanksi terhadap seseorang yang belum dewasa dengan orang dewasa yang melakukan perbuatan pidana, dengan perbedaan tersebut, terhadap hukuman pidana anak, telah diatur didalam undang-undang khusus anak yang digolongkan dalam beberapa diantaranya: Undang-undang Nomor 11 Tahun 2012 tentang Sistem Peradilan Pidana Anak, Undang-undang Nomor 23 Tahun 2002 tentang Perlindungan Anak, Undangundang Nomor 4 tahun 1979 tentang Kesejahteraan Anak.

Dari hasil penyidikan, bahwa perbuatan pelaku masih berusia di bawah umur telah dapat dibuktikan secara sah dan meyakinkan memenuhi rumusan tindak pidana lakalantas yang dikenakan dalam Pasal 310 ayat (3) UU No. 22 tahun 2009 tentang Lalulintas dan Angkutan Jalan. Yakni: "bahwa "setiap orang yang mengemudikan Kendaraan Bermotor yang karena kelalaiannya mengakibatkan Kecelakaan Lalu Lintas dengan korban luka berat sebagaimana dimaksud dalam Pasal 229 ayat (4), dipidana dengan pidana penjara paling lama 5 (lima) tahun dan/atau denda paling banyak Rp10.000.000,00 (sepuluh juta rupiah).

Pasal 229 ayat (4) UU No. 22 Tahun 2009 tentang Lalulintas dan Angkutan Jalan menyatakan bahwa "kecelakaan Lalu Lintas berat sebagaimana dimaksud pada ayat (1) huruf c merupakan kecelakaan yang mengakibatkan korban meninggal dunia atau luka berat."

Hukuman atau sanksi dan proses hukum dalam kasus pelanggaran hukum oleh anak berbeda dengan kasus pelanggaran hukum oleh orang dewasa, karena dasar pemikiran pemberian hukuman oleh negara adalah bahwa setiap warga negaranya adalah mahkluk yang bertanggungjawab dan mampu mempertanggungjawabkan segala perbuatannya.

Langkah upaya yang dilakukan Satlantas Polres Langkat dalam penanganan tindak pidana laka lantas pelaku anak dibawah umur dimana penyidik wajib untuk memediasi kedua belah pihak yang terlibat adalah telah menerima laporan dari korban, lalu terbit Laporan Polisi (LP) kemudian dibuatkan Surat Perintah Penyidikan dan penyidik menerapkan restorative justice dengan mengupayakan sistem diversi, penyidik mengirim surat Ke Balai Pemasyarakatan (Bapas) dengan tujuan untuk pendampingan pelaku tindak pidana laka lantas anak dibawah umur dan melakukan penelitian masyarakat dan mendampingi selama penyidikan.

Penyidik mengirim surat ke Penasehat Hukum untuk pendampingan pelaku tindak pidana laka lantas anak dibawah umur selama penyidikan. Sistem Diversi dengan dilaksanakan dihadiri para pihak, yaitu pihak korban didampingi oleh keluarga serta perangkat desa sedangkan pihak tersangka hadir didampingi keluarga dan perangkat desa serta Balai Pemasyarakatan dan Penasehat Hukum.

Apabila sudah tercapai kesepakatan diversi maka korban telah menyetujui bahwa perkara diselesaikan secara kekeluargaan dan tidak menuntut ke jalur hukum. Selanjutnya penyidik mengirim Surat kesepakatan Diversi dan Berita Acara kesepakatan diversi ke Pengadilan Negeri selanjutnya akan mendapatkan putusan dari Pengadilan Negeri yang isinya memerintahkan penyidik untuk menghentikan penyidikan. Apabila tercapai kesepakatan diversi Penyidik hanya mengirim surat kesepakatan diversi dan Berita Acaranya untuk mendapatkan putusan/penetapan Diversi dari Pengadilan Negeri. Namun apabila tidak tercapai kesepakatan Diversi berarti korban masih menuntut dan penyidik tetap melanjutkan perkara sesuai undangundang yang berlaku.

Apabila tidak tercapai kesepakatan diversi Penyidik mengirim SPDP (Surat Pemberitahuan Dimulainya Penyidikan) ke Kejaksaan. Selanjutnya diproses sesuai Undang-Undang Peradilan Anak No 11 tahun 2012.

Sanksi yang dapat diberikan kepada seorang anak dibawah umur, bahwa seorang anak yang belum berusia dua belas (12) tahun, belum dapat diajukan ke depan persidangan anak, 
walaupun seorang anak tersebut telah melakukan suatu perbuatan tindak pidana. Dikarenakan hal ini didasarkan pada pertimbangan sosiologis, psikologis dan paedagogis, bahwa anak yang belum berumur 12 (dua belas) tahun itu belum dapat mempertanggungjawabkan perbuatannya (Prakoso, 2013).

Pertanggungjawaban terhadap anak di bawah umur yang menyebabkan luka berat atau hilangnya nyawa seseorang dalam tindak pidana lakalantas dapat diajukan kedepan peradilan dan dapat dimintai pertanggungjawaban dengan berdasarkan ketentuan yang telah diatur dalam UU No 11 Tahun 2012 tentang Sistem Peradilan Anak dan telah diatur ketentuan hukum pidana dengan $1 / 2$ (satu perdua) hukuman dari orang dewasa.

\section{SIMPULAN}

Pengaturan hukum tindak pidana lakalantas pelaku anak dibawah umur. Unsur-unsur adanya karena kelalaiandalam mengenderai kendaraan sehingga menyebabkan korban pengaturannya ditentukan oleh Pasal 229UU No. 22 Tahun 2009 tentang Lalulintas dan Angkutan Jalan. Sedangkan pengaturan unsur-unsur sekaligus sanksi tindak pidana lakalantas yang korban mengalami luka berat menurut UU No. 22 Tahun 2009 tentang Lalu lintas dan Angkutan Jalan diatur oleh Pasal 310 ayat (3). Dalam hal ini, Penyidikan dilakukan melalui tahapan pemeriksaan tersangka, pemeriksaan terhadap saksi-saksi, beserta pemeriksaan terhadap bukti-bukti. Dalam membebani pertanggungjawaban pidana terhadap anak sebagai pelaku yang masih berusia dibawah umur yang melakukan tindak pidana lakalantas harus terpenuhi syarat segala unsur-unsur kejahatan dan maksud dari tujuan perbuatan tersebut harus dapat dibuktikan bahwa memang sengaja diperbuat dengan kondisi sadar akan di langgarnya suatu perbuatan pidana yang diatur oleh suatu peraturan perundang-undangan. Hukuman atau sanksi dan proses hukum dalam kasus pelanggaran hukum oleh anak berbeda dengan kasus pelanggaran hukum oleh orang dewasa, dalam penyidikan kasus anak di bawah umur yang melakukan tindak pidana lakalantas penyidik harus menerapkan restorative justice dengan mengupayakan sistem diversi diproses sesuai UU No 11 Tahun 2012 tentang Sistem Peradilan Anak.

\section{DAFTAR PUSTAKA}

Atmasasmita, R (1983), Problema Kenakalan Anak-Anak Remaja,, Bandung: Armico.

Bunga, D (2012), Prostitusi Cyber Penegakan Hukum Dalam Anatomi Kejahatan Transnasional, Denpasar: Udayana University Press.

Dermawan, A. (2020). Urgensi Perlindungan Hukum Bagi Korban Kecelakaan Lalu Lintas Menurut UndangUndang Nomor 22 Tahun 2009 Tentang Lalu Lintas dan Angkutan Jalan. Doktrina: Journal Of Law, 3(1), 77-86. doi:https://doi.org/10.31289/doktrina.v3i1.3527

Ediwarman. (2014). Monograf Metodologi Penelitian Hukum (Panduan Penelitian Tesis dan Disertasi). Medan: Program Pascasarjana Universitas Muhammadiyah Sumatera Utara

Hamzah, A (1996), Hukum Acara Pidana Indonesia, Jakarta: CV. Sapta Artha Jaya.

Husein, H.M. (1991), Penyidikan dan Penuntutan Dalam Proses Pidana, Jakarta:Rinneka Cipta.

Ikhwan, M., Sahari, A., \& Fauzi, A. (2020). Peran Direktorat Lalu Lintas Polda Sumatera Utara Dalam Menciptakan Akuntabilitas Pelayanan Publik. Journal of Education, Humaniora and Social Sciences (JEHSS), 3(1), 103-110. doi:https://doi.org/10.34007/jehss.v3i1.204

Poerwadarminta, WJS (1985), Kamus Umum Bahasa Indonesia, Jakarta: Eresco.

Prakoso, A (2013), Pembaharuan Sistem Peradilan Pidana Anak, Yogyakarta: Laksbang Grafika.

Siregar, R.D.W, Mubarak, R \& Zulyadi, R. (2019). Peranan Kepolisian Dalam Penerapan Restorative Justice Terhadap Kecelakaan Lalu Lintas Di Wilayah Polsek Deli Tua (Studi Kasus Polsek Delitua). JUNCTO, 1(2) 2019: 150-157,

Soekanto, S (2004), Faktor-Faktor Yang Mempengaruhi Penegakan Hukum, Jakarta: Rajawali Press.

Wahyuni, F., Eddy, T., Eddy, T., Sahari, A., \& Sahari, A. (2020). Penegakan Hukum Persidangan Cepat Dalam Penyelesaian Perkara Pelanggaran Lalu Lintas (Studi Satlantas Polrestabes Medan). Journal of

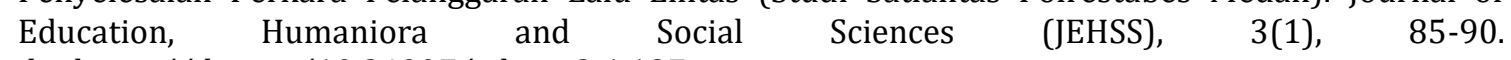
doi:https://doi.org/10.34007/jehss.v3i1.197 